\title{
Studies on Zoospore-Attracting Activity. I. Synthesis of Isoflavones and Their Attracting Activity to Aphanomyces euteiches Zoospore
}

\author{
HARUo SEKIZAKI ${ }^{* a}$ and Ryozo YoKosaWA ${ }^{b}$ \\ Faculty of Pharmaceutical Science and Department of General Education, ${ }^{b}$ \\ Higashi Nippon Gakuen University, Ishikari-Tobetsu. \\ Hokkaido 061-02, Japan
}

(Received May 26, 1988)

\begin{abstract}
Prunetin (2) and its derivatives were synthesized in order to study the relationship between structure and attracting activity to Aphanomyces euteiches zoospore. All of the derivatives (1, 2, 4 and 6), which had a hydroxyl group at the C-5 position in the isoflavone, showed attracting activity, but the methyl ether derivatives $(3,5,7$ and 8$)$ do not have or have very weak attracting activity. The isoflavones (1, 2 and 4 ) with strong attracting activity also had estrogenic activity.
\end{abstract}

Keywords_—isoflavone; prunetin; genistein; biochanin A; 5-methylgenistein; 5-hydroxy-4',7dimethoxyisoflavone; Aphanomyces euteiches; zoospore; attracting activity; estrogenic activity

\section{Introduction}

It is well-known that zoospores of zoosporic plant pathogens are attracted to the underground parts of plants and this attraction is mediated by chemical substances. ${ }^{1-5)} \mathrm{We}$ reported the isolation of 7-methoxy-4',5-dihydroxyisoflavone (prunetin) (2) from pea root, and showed that it strongly attracted Aphanomyces euteiches zoospore at the concentration of $5 \times 10^{-7} \mathrm{M}$ in aqueous solution. ${ }^{6)}$ It was also reported that prunetin (2) has estrogenic activity, ${ }^{7,8)}$ hypolipidemic activity, ${ }^{9)}$ antioxidative activity for edible oil ${ }^{10)}$ and a stimulative effect on indole acetic acid oxidase. ${ }^{11}$ ) The attraction test, which was used for the previous study, ${ }^{6}$ is simple, rapid and precise. We are interested in the relationship between the structure and attracting activity, and in the application of this attraction test for pre-screening of pharmacologically useful compounds. This report deals with the synthesis of prunetin (2) and its derivatives shown in Table I, and with the relationship between the structure of these compounds and their attracting activity to A. euteiches zoospore. The possiblity of a correlation between zoospore-attracting activity and estrogenic activity is also discussed.

\section{Synthesis}

The seven isoflavones were prepared as follows and identified on the basis of their physical properties and spectroscopic analyses, as well as by direct comparison with authentic samples.

4',5,7-Trihydroxyisoflavone (genistein) (1), 5-hydroxy-4',7-dimethoxyisoflavone (6) and $4^{\prime}, 5,7$-trimethoxyisoflavone (8) were derived from the commercial 5,7-dihydroxy-4'-methoxyisoflavone (biochanin $\mathrm{A})(\mathbf{4})$ by demethylation with aluminium chloride in benzene, by partial methylation with diazomethane in ether and by permethylation with dimethyl sulfate and anhydrous potassium carbonate in acetone, respectively.

$4^{\prime}$-Hydroxy-5,7-dimethoxyisoflavone (5) was synthesized by oxidative rearrangement of the $2^{\prime}$-hydroxychalcone $(\mathbf{1 0})$, which was prepared by the usual potassium hydroxide-catalyzed condensation of the 2'-hydroxy-4',6'-dimethoxyacetophenone (9) and 4-hydroxybenzaldehyde (11) according to Heitz and Mentzen ${ }^{12)}$ with thallium(III) nitrate trihydride (TTN) in 


$$
\begin{aligned}
& \text { 管OH } \\
& \text { 9: } R_{1}=R_{2}=M e, \quad 11: \quad R_{3}=H \quad 10: \quad R_{1}=R_{2}=M e \text {, } \\
& \mathrm{R}_{4}=\mathrm{H} \quad 16: \quad \mathrm{R}_{3}=\mathrm{CH}_{2} \mathrm{Ph} \quad \mathrm{R}_{3}=\mathrm{R}_{4}=\mathrm{H} \\
& \text { 12: } R_{1}=R_{2}=R_{4}=H \quad 17: R_{1}=R_{4}=H \text {, } \\
& \text { 13: } \mathrm{R}_{1}=\mathrm{H}, \quad \mathrm{R}_{2}=\mathrm{Me} \text {, } \\
& \mathbf{R}_{2}=\mathbf{R}_{\mathbf{4}}=\mathrm{Ac} \\
& \text { 14: } \quad R_{1}=R_{4}=A c \\
& \mathrm{R}_{2}=\mathrm{H} \\
& \mathrm{R}_{3}=\mathrm{CH}_{2} \mathrm{Ph} \\
& \text { 19: } \quad R_{1}=R_{4}=H \text {, } \\
& \mathrm{R}_{2}=\mathrm{R}_{\mathbf{3}}=\mathrm{Me} \\
& \text { 5: } \mathbf{R}_{1}=\mathrm{R}_{2}=\mathrm{Me} \text {, } \\
& \mathrm{R}_{3}=\mathrm{H} \\
& \text { 18: } \mathrm{R}_{1}=\mathrm{H} \text {, } \\
& \mathrm{R}_{2}=\mathrm{Me} \text {, } \\
& \mathrm{R}_{3}=\mathrm{CH}_{2} \mathrm{Ph} \\
& \text { 7: } \mathrm{R}_{1}=\mathrm{H} \text {, } \\
& \mathrm{R}_{2}=\mathrm{R}_{3}=\mathrm{Me}
\end{aligned}
$$

\section{Chart 1}

methanol then acid-catalyzed ring closure of the resulting acetal according to Farkas et al. ${ }^{13)}$ Prunetin (2) was derived from 5 by partial demethylation with aluminium chloride in nitrobenzene.

4',7-Dihydroxy-5-methoxyisoflavone (5-methylgenistein) (3) was prepared by the route shown in Chart 1. Acetylation of phloroacetophenone (12) by Büchi et al.'s procedure ${ }^{14)}$ gave $2^{\prime}, 6^{\prime}$-diacetoxy-4'-hydroxyacetophenone (13) and 2',4'-diacetoxy-6'-hydroxyacetophenone (14). Methylation of the 14 with diazomethane afforded $2^{\prime}, 4^{\prime}$-diacetoxy-6'-methoxyacetophenone (15). The usual potassium hydroxide-catalyzed condensation of the acetophenone (15) and 4-benzyloxybenzaldehyde (16) afforded the benzyloxychalcone (17). Oxidative rearrangement of 17 with TTN in methanol then acid-catalyzed ring closure produced the 4'-benzyloxy-7-hydroxy-5-methoxyisoflavone (18). Deprotection of 18 with $10 \%$ Pd-oncarbon afforded 5-methylgenistein (3). 4',5-Dimethoxy-7-hydroxyisoflavone (7) was also prepared by a procedure similar to that described above using the $p$-anisaldehyde.

\section{Zoospore Formation}

A. euteiches isolate (AE-F3) was grown for $3-4 \mathrm{~d}$ on a corn meal agar plate at $25^{\circ} \mathrm{C}$. The agar plate bearing mycelium was transferred to a Petri dish containing distilled water, and it was rinsed with four changes of distilled water then incubated for $12-20 \mathrm{~h}$ at $25^{\circ} \mathrm{C}$ to make zoospore.

\section{Attraction Test}

A $10^{-5}-10^{-9} \mathrm{M}$ methanolic solution of a test sample was introduced into a glass capillary tube and the solvent was allowed to evaporate spontaneously in order to avoid the effect of methanol on zoospores. Then the capillary tube was filled with distilled water and one end was sealed. The unsealed end of the capillary test tube was inserted into a zoospore suspension and the behavior of zoospores was observed under a microscope. The attracting activity was judged positive if the zoospores swam to mass within a few seconds at the end of the test capillary tube. The extent zoospore migration and persistence of attractiveness were variable, depending on the concentration or compound used, as shown in Table I.

\section{Results and Discussion}

Genistein (1), prunetin (2), 5-methylgenistein (3) and biochanin A (4) are naturally occurring isoflavones, and were synthesized by Baker et al. ${ }^{15)}$ Genistein (1) was originally isolated as a glycoside from Genista trictoria (Leguminosae) ${ }^{16)}$ and was well investigated in connection with the estrogenic properties of Trifolium spp. (Leguminosae). ${ }^{17,18)}$ Prunetin (2) was originally isolated as a glucoside from the bark of a species of wild cherry closely related 
TABLE I. Attracting Activity of Isoflavones to Zoospores of Aphanomyces euteiches (AE-F3)

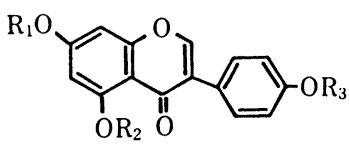

\begin{tabular}{ccccccccc}
\hline \hline \multirow{2}{*}{$\begin{array}{c}\text { Compd. } \\
\text { No. }\end{array}$} & $\mathrm{R}_{1}$ & $\mathrm{R}_{2}$ & $\mathrm{R}_{3}$ & & \multicolumn{6}{c}{ Degree of attracting activity ${ }^{a}$ and concentration (M) } \\
\cline { 5 - 8 } & & & & $10^{-5}$ & $10^{-6}$ & $10^{-7}$ & $10^{-8}$ & $10^{-9}$ \\
\hline $\mathbf{1}$ & $\mathrm{H}$ & $\mathrm{H}$ & $\mathrm{H}$ & +++ & ++ & + & - & - \\
$\mathbf{2}$ & $\mathrm{Me}$ & $\mathrm{H}$ & $\mathrm{H}$ & ++++ & ++++ & ++ & + & - \\
$\mathbf{3}$ & $\mathrm{H}$ & $\mathrm{Me}$ & $\mathrm{H}$ & + & - & - & - & - \\
$\mathbf{4}$ & $\mathrm{H}$ & $\mathrm{H}$ & $\mathrm{Me}$ & +++ & ++ & + & - & - \\
$\mathbf{5}$ & $\mathrm{Me}$ & $\mathrm{Me}$ & $\mathrm{H}$ & - & - & - & - & - \\
$\mathbf{6}$ & $\mathrm{Me}$ & $\mathrm{H}$ & $\mathrm{Me}$ & +++ & ++ & + & - & - \\
$\mathbf{7}$ & $\mathrm{H}$ & $\mathrm{Me}$ & $\mathrm{Me}$ & - & - & - & - & - \\
$\mathbf{8}$ & $\mathrm{Me}$ & $\mathrm{Me}$ & $\mathrm{Me}$ & - & - & - & - & - \\
\hline
\end{tabular}

a),- no effect; + , attractive effect vanishes with $10 \mathrm{~min} ;++$, attractive effect persists 10 to $30 \mathrm{~min}$; +++ , attractive effect persists 30 to $60 \mathrm{~min} ;++++$, attractive effect persists more than $60 \mathrm{~min}$.

to Prunus emarginata (Rosaceae). ${ }^{19)}$ 5-Methylgenistein (3) was originally isolated from Ormosa excelsa (Leguminosae) by Gottieb and Darocha. ${ }^{20)}$ Biochanin A (4) was the first nonglucosidic isoflavone from a plant ${ }^{21)}$ and was also investigated in connection with the estrogenic properties of meadow. ${ }^{17,18)}$

$4^{\prime}$-Hydroxy-5,7-dimethoxyisoflavone (5), ${ }^{22)}$ 5-hydroxy-4',7-dimethoxyisoflavone (6), ${ }^{23)}$ 7-hydroxy-4',5-dimethoxyisoflavone $(7)^{23)}$ and $4^{\prime}, 5,7$-trimethoxyisoflavone $(8)^{17)}$ were synthetic substances.

As shown in Table I, the naturally occurring isoflavones $(1-4)$ had attracting activity to A. euteiches zoospores, and prunetin (2), which was attractive at the concentration of $10^{-8} \mathrm{M}$ in aqueous solution, was the most potent among them. Genistein (1) and biochanin A (4) were active at the concentration of $10^{-7} \mathrm{M}$ in aqueous solution, and were slightly less potent than prunetin (2), while 5-methylgenistein (3) had very weak activity. Another four synthetic isoflavones $(5-8)$ were significantly less active, except the 5-hydroxy-4',7-dimethoxyisoflavone (6).

These results showed that the hydroxyl group at the C-5 position in 4',5,7-trioxygenated isoflavones is necessary for strong attracting activity. The methylation of the C-7 hydroxyl group increased the attracting activity and that of the C-4' hydroxyl group had no effect, but methylation of the C-5 hydroxyl group decreased the attracting activity.

On the other hand, it was reported that genistein (1), prunetin (2) and biochanin A (4) have estrogenic properties. ${ }^{7,24)}$ The estrogenic activity and attracting activity of isoflavones seem to be correlated, and we intent to carry out further work in order to judge the usefulness of this attraction test for the pre-screening of phyto-estrogenic compounds.

\section{Experimental}

Melting points were determined on a Yanagimoto micro melting point apparatus and are uncorrected. Infrared (IR) spectra were taken on a Hitachi 270-30 infrared spectrophotometer. Ultraviolet (UV) spectra were obtained with a Shimadzu UV-210 spectrophotometer. Proton nuclear magnetic resonance $\left({ }^{1} \mathrm{H}-\mathrm{NMR}\right)$ spectra were recorded on a JEOL FX-90Q spectrometer and the chemical shifts are expressed in ppm from tetramethylsilane as an internal standard; s, singlet; d, doublet; $t$, triplet; dd, doublet of doublets; m, multiplet. Mass spectra (MS) were taken on 
Shimadzu LKB-9000 and JEOL PM-60 spectrometers by the direct inlet method; ionization voltage $70 \mathrm{eV}$. Column chromatography was carried out with Kanto silica gel.

Biochanin A (4)-Biochanin A (4), purchased from Aldrich Co., was used after purification through silica gel column chromatography (benzene-ethyl acetate; $1: 1$ ). $\mathrm{mp} 214-5^{\circ} \mathrm{C}(\mathrm{EtOH})$.

Genistein (1)-Biochanin A (4) (142 mg, $0.5 \mathrm{mmol})$ was suspended in $7 \mathrm{ml}$ of dry benzene, and $165 \mathrm{mg}$ $(1.25 \mathrm{mmol})$ of anhydrous aluminium chloride was added to the suspension to yield a clear yellowish brown solution. The reaction mixture was refluxed for $18 \mathrm{~h}$ and then poured into ice-water containing dilute hydrochloric acid. The acidic solution was extracted with ethyl acetate and washed successively with saturated aqueous sodium chloride and water. The solvent was distilled off and the residue was purified by silica gel column chromatography (benzene-ethyl acetate; $2: 1)$ to yield $63.1 \mathrm{mg}(47 \%)$ of 1 as slightly yellow needles, $\mathrm{mp} 279-298{ }^{\circ} \mathrm{C}(\mathrm{EtOH})$.

5-Hydroxy-4',7-dimethoxyisoflavone (6)-Biochanin A (4) $(200 \mathrm{mg}, 0.7 \mathrm{mmol})$ was suspended in $3 \mathrm{ml}$ of ether, and an excess of diazomethane solution in ether was added. The reaction mixture was left standing for $30 \mathrm{~h}$ at room temperature. The solvent was distilled off and the residue was purified by silica gel column chromatography (benzene-ethyl acetate; $1: 1)$ to yield $175 \mathrm{mg}(84 \%)$ of 6 as slightly yellow needles, $\mathrm{mp} 139-140{ }^{\circ} \mathrm{C}(\mathrm{EtOH})$.

4',5,7-Trimethoxyisoflavone (8)-Biochanin A (4) $(142 \mathrm{mg}, 0.5 \mathrm{mmol})$ was dissolved in $5 \mathrm{ml}$ of dry acetone. Anhydrous potassium carbonate $(345 \mathrm{mg}, 2.5 \mathrm{mmol})$ was added to the solution, and then dimethyl sulfate $(0.1 \mathrm{ml}$, $1.1 \mathrm{mmol}$ ) was added. The mixture was refluxed for $18 \mathrm{~h}$, and then the solvent was distilled off. The residue was dissolved in water and extracted with ethyl acetate. The extract was washed successively with saturated aqueous sodium chloride and water. The solvent was distilled off and the residue was purified by silica gel column chromatography (benzene-ethyl acetate; $6: 1)$ to yield $154 \mathrm{mg}(98 \%)$ of 8 as slightly yellow needles, mp $162-163{ }^{\circ} \mathrm{C}$ (EtOH).

4'-Hydroxy-5,7-dimethoxyisoflavone (5)-The chalcone (10) $(1.8 \mathrm{~g}, 6 \mathrm{mmol})$ was dissolved in $400 \mathrm{ml}$ of methanol, and $5.86 \mathrm{~g}(13.2 \mathrm{mmol})$ of TTN was added at room temperature. The reaction mixture was stirred for an additional $15 \mathrm{~min}$, and then $20 \mathrm{ml}$ of $3 \mathrm{~N}$ hydrochloric acid was added to yield a small amount of yellow precipitate, and the reaction mixture was refluxed for $4.5 \mathrm{~h}$. The solvent was distilled off and the residue was dissolved in a mixture of ethyl acetate and saturated aqueous sodium chloride. The organic layer was separated from the aqueous layer, and washed with saturated aqueous sodium chloride and water. The solvent was distilled off and the residue was purified by silica gel column chromatography (benzene-ethyl acetate; $1: 1)$ to yield $1.362 \mathrm{~g}(75 \%)$ of 5 as slightly yellow needles, $\mathrm{mp} 180-182^{\circ} \mathrm{C}(\mathrm{EtOH})$.

Prunetin (2)-Compound $5(143 \mathrm{mg}, 0.48 \mathrm{mmol})$ was suspended in $15 \mathrm{ml}$ of nitrobenzene and $2.5 \mathrm{~g}(18.8 \mathrm{mmol})$ of anhydrous aluminium chloride was added to the suspension to yield a clear black solution. The reaction mixture was stirred for $2.5 \mathrm{~h}$ at room temperature. The reaction mixture was then poured into ice-water containing $4 \mathrm{ml}$ of $3 \mathrm{~N}$ hydrochloric acid and extracted with ethyl acetate. The organic layer was washed with saturated aqueous sodium chloride. The solvent was distilled off and the residue was steam-distilled until nitrobenzene could not be detected in a mixture. The solid residue was collected by filtration, washed with water and purified by silica gel column chromatography (benzene-ethyl acetate; $2: 1)$ to yield $98 \mathrm{mg}(72 \%)$ of 2 as colorless needles, $\mathrm{mp} 246-248{ }^{\circ} \mathrm{C}$ $(\mathrm{MeOH})$.

2'4'-Diacetoxy-6'-methoxyacetophenone (15)-2 - 2'4'-Diacetoxy-6'-hydroxyacetophenone (14) (2.9 g, 11.5 $\mathrm{mmol}$ ) was dissolved in $30 \mathrm{ml}$ of ether and an excess diazomethane solution in ether was added. The reaction mixture was left standing for $12 \mathrm{~h}$ at room temperature. The solvent was distilled off and the oily residue was purified by silica gel column chromatography (benzene-ethyl acetate; $15: 1$ ) to yield $2.5 \mathrm{~g}(82 \%)$ of 15 as a colorless viscous oil. UV $i_{\text {max }}^{\mathrm{EtOH}} \mathrm{nm}(\log \varepsilon): 275$ (sh, 3.45), 250 (3.57). IR $v_{\max }^{\text {neat }} \mathrm{cm}^{-1}: 1773,1698,1611,1371,1257,1197,1134,1098,1065$, 1026. MS $m / z(\%): 266\left(\mathrm{M}^{+}, 4\right), 224(26), 182(40), 167(100) .{ }^{1} \mathrm{H}-\mathrm{NMR}\left(\mathrm{CDCl}_{3}\right) \delta: 2.19\left(3 \mathrm{H}, \mathrm{s},-\mathrm{OCOCH}_{3}\right), 2.35(3 \mathrm{H}$, s, $\left.-\mathrm{OCOCH}_{3}\right), 2.45\left(3 \mathrm{H}, \mathrm{s},-\mathrm{COCH}_{3}\right), 6.49\left(1 \mathrm{H}, \mathrm{d}, J=2.2 \mathrm{~Hz}, \mathrm{H}-3^{\prime}\right.$ or H-5'), $6.75\left(1 \mathrm{H}, \mathrm{d}, J=2.2 \mathrm{~Hz}, \mathrm{H}-3^{\prime}\right.$ or H-5').

4-Benzyloxy-2',4'-dihydroxy-6'-methoxychalcone (17)_CCompound 15 (1.255 g, $4.7 \mathrm{mmol}$ ) and $p$-benzyloxybenzaldehyde (16) $(953 \mathrm{mg}, 4.7 \mathrm{mmol})$ were dissolved in $10 \mathrm{ml}$ of ethanol. An aqueous solution of potassium hydroxide $(2.07 \mathrm{~g}, 31.5 \mathrm{mmol})$ in $2 \mathrm{ml}$ of water was added to the mixture under ice-cooling and stirring to yield a clear reddish brown solution. The reaction mixture was allowed to react at room temperature for $24 \mathrm{~h}$ and was then poured into ice-water and acidified with $11 \mathrm{ml}$ of $3 \mathrm{~N}$ hydrochloric acid. The acidic solution was extracted with ethyl acetate. The organic layer was separated from the aqueous layer, and washed with saturated aqueous sodium chloride and water. The solvent was distilled off and the residue was purified by silica gel column chromatography (benzene-ethyl acetate; $6: 1)$ to yield $832 \mathrm{mg}\left(47_{0} \%\right)$ of 17 as yellow needles, $\mathrm{mp} 228-229^{\circ} \mathrm{C}(\mathrm{EtOH})$. UV $\lambda_{\max }^{\mathrm{EtOH}} \mathrm{nm}(\log \varepsilon): 363(4.58)$,

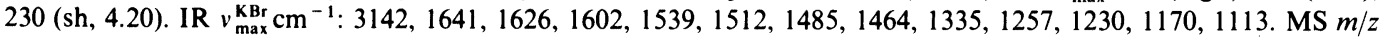
$(\%): 376\left(\mathrm{M}^{+}, 57\right), 285(44), 197(56), 167(63), 147(58), 65(100) .{ }^{1} \mathrm{H}-\mathrm{NMR}\left(\mathrm{CD}_{3} \mathrm{OD}\right) \delta: 3.93\left(3 \mathrm{H}, \mathrm{s}, \mathrm{OCH}_{3}\right), 5.14$ $\left(2 \mathrm{H}, \mathrm{s},-\mathrm{CH}_{2} \mathrm{Ph}\right), 5.92\left(1 \mathrm{H}, \mathrm{d}, J=2.2 \mathrm{~Hz}, \mathrm{H}-3^{\prime}\right), 6.01\left(1 \mathrm{H}, \mathrm{d}, J=2.2 \mathrm{~Hz}, \mathrm{H}-5^{\prime}\right), 6.98(2 \mathrm{H}, \mathrm{d}, J=8.8 \mathrm{~Hz}, \mathrm{H}-3 \mathrm{and} \mathrm{H}-5)$, $7.39(5 \mathrm{H}, \mathrm{m}, \mathrm{PhH}), 7.65(2 \mathrm{H}, \mathrm{d}, J=8.8 \mathrm{~Hz}, \mathrm{H}-2$ and $\mathrm{H}-6), 7.72(1 \mathrm{H}, \mathrm{s}, \mathrm{H}-\alpha$ or $\mathrm{H}-\beta), 7.77(1 \mathrm{H}, \mathrm{s}, \mathrm{H}-\alpha$ or $\mathrm{H}-\beta)$.

4'-Benzyloxy-7-hydroxy-5-methoxyisoflavone (18)_Compound $17(189.6 \mathrm{mg}, 0.5 \mathrm{mmol})$ was suspended in $50 \mathrm{ml}$ of methanol, and $488.4 \mathrm{mg}(1.1 \mathrm{mmol})$ of TTN was added to the suspension to yield a clear yellow solution. The reaction mixture was stirred for $2 \mathrm{~h}$ at room temperature. Then $3 \mathrm{ml}$ of $3 \mathrm{~N}$ hydrochloric acid was added to the clear solution to yield a small amount of yellow precipitate, and the reaction mixture was refluxed for $4.5 \mathrm{~h}$. The solvent 
was distilled off and the residue was dissolved in a mixture of ethyl acetate and saturated aqueous sodium chloride. The organic layer was separated from the aqueous layer, and washed with saturated sodium chloride and water. The solvent was distilled off and the residue was purified by silica gel column chromatography (benzene-ethyl acetate; $1: 1)$ to yield $123.3 \mathrm{mg}(66 \%)$ of 18 as slightly yellow fine needles, mp $296-298 \mathrm{C}(\mathrm{EtOH})$. UV $i_{\max }^{\mathrm{EtOH}} \mathrm{nm}(\log \varepsilon): 390$

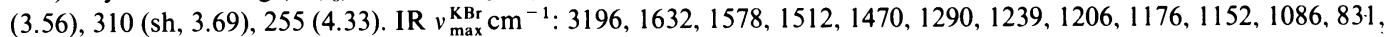
746. MS $m / z(\%): 374\left(\mathrm{M}^{+}, 28\right), 283(22), 91(100) .{ }^{1} \mathrm{H}-\mathrm{NMR}\left(\mathrm{CDCl}_{3}: \mathrm{DMSO}-d_{6} ; 5: 1\right) \delta: 3.90\left(3 \mathrm{H}, \mathrm{s}, \mathrm{OCH}_{3}\right), 5.09(2 \mathrm{H}$, $\left.\mathrm{s},-\mathrm{CH}_{2} \mathrm{Ph}\right), 6.39(1 \mathrm{H}, \mathrm{d}, J=2.2 \mathrm{~Hz}, \mathrm{H}-6), 6.46(1 \mathrm{H}, \mathrm{d}, J=2.2 \mathrm{~Hz}, \mathrm{H}-8), 6.97\left(2 \mathrm{H}, \mathrm{d}, J=8.8 \mathrm{~Hz}, \mathrm{H}-3^{\prime}\right.$ and $\left.\mathrm{H}_{-5}\right), 7.40$ $(5 \mathrm{H}, \mathrm{m}, \mathrm{PhH}), 7.45\left(2 \mathrm{H}, \mathrm{d}, J=8.8 \mathrm{~Hz}, \mathrm{H}-2^{\prime}\right.$ and $\left.\mathrm{H}-6^{\prime}\right), 7.78(1 \mathrm{H}, \mathrm{s}, \mathrm{H}-2)$.

5-Methylgenistein (3) Compound (18) $(78.6 \mathrm{mg}, 0.21 \mathrm{mmol})$ was dissolved in $20 \mathrm{ml}$ of ethanol and the solution was stirred under atmospheric pressure of $\mathrm{H}_{2}$ in the presence of $10 \%$ Pd-on-carbon $(70.5 \mathrm{mg})$ for $48 \mathrm{~h}$ at room temperature. The catalyst was filtered off and the filtrate was distilled off. The residue was purified by silica gel column chromatography (ethyl acetate) to yield $59.7 \mathrm{mg}(81 \%)$ of 3 as slightly yellow fine needles, $\mathrm{mp} 218-220^{\circ} \mathrm{C}$ (EtOH).

7-Hydroxy-4',5-dimethoxyisoflavone (7)_- The chalcone $19^{24)}(294 \mathrm{mg}, 1.04 \mathrm{mmol})$ was dissolved in $70 \mathrm{ml}$ of methanol, and $234 \mathrm{mg}(2.3 \mathrm{mmol})$ of TTN was added. The mixture was stirred for $30 \mathrm{~min}$ at room temperature. Then $3.5 \mathrm{ml}$ of $3 \mathrm{~N}$ hydrochloric acid was added to the clear solution to yield a small amount of precipitate, and the reaction mixture was refluxed for $6 \mathrm{~h}$. The solvent was distilled off and the residue was dissolved in a mixture of ethyl acetate and saturated aqueous sodium chloride. The organic layer was separated from the aqueous layer, and washed with saturated aqueous sodium chloride and water. The solvent was distilled off and the residue was purified by silica gel column chromatography (ethyl acetate) to yield $132.5 \mathrm{mg}(45 \%)$ of 7 as colorless needles, mp $291-292 \mathrm{C}(\mathrm{EtOH})$.

Fungus and Zoospore Formation_An A. euteiches isolate (AE-F3), which was isolated from pea root rot field soils, was used. The fungus was grown for 3-4 d on corn meal agar plates at $25^{\circ} \mathrm{C}$. Each agar plate bearing mycelia was transferred to a Petri dish, $15 \mathrm{~cm}$ in diameter, containing $400 \mathrm{ml}$ of distilled water and it was rinsed with four changes of distilled water within $2 \mathrm{~h}$ to remove nutrient material inhibitory to zoospore formation. The material thus rinsed was then incubated for $12-20 \mathrm{~h}$ at $25^{\circ} \mathrm{C}$. Zoospore concentration was adjusted to $5000 / \mathrm{ml}$ with distilled water.

Attraction Test-A methanolic solution of the test sample $\left(10^{-5}-10^{-9} \mathrm{M}\right)$ was introduced into a glass capillary tube $(2.5 \mathrm{~cm}$ long, $0.8 \mathrm{~mm}$ outer diameter $)$ and the solvent allowed to evaporate spontaneously. Then the capillary tube was filled with distilled water and one end was sealed with vaseline. A $2 \mathrm{~cm}$ part from the unsealed end of the capillary tube was inserted stanting into the zoospore suspension in a small plastic vessel $(44 \mathrm{~mm}$ long, $22 \mathrm{~mm}$ wide and $5 \mathrm{~mm}$ high) on a microscope stage, and the behavior of the zoospores was observed at a magnification of $40 \times$.

\section{References}

1) D. J. Royle and C. J. Hickman, Can. J. Microbiol., 10, 151 (1964).

2) P. V. Rai and G. A. Strobel, Phytopathology, 56, 1365 (1966).

3) H. H. Ho and C. J. Hickman, Can. J. Bot., 45, 1983 (1967).

4) K. Suzuki and M. Takahashi, Ann. Phytopath. Soc. Jpn., 44, 241 (1978).

5) R. Yokosawa and S. Kuninaga, Ann. Phytopath. Soc. Jpn., 45, 339 (1979).

6) R. Yokosawa, S. Kuninaga and H. Sekizaki, Ann. Phytopath. Soc. Jpn., 52, 809 (1986).

7) B. Maymone, Ann. Ist. Sper. Zootec. Roma, 10, 195 (1963).

8) H. Schaner, Dtsch. Apoth.-Ztg., 104, 987 (1964).

9) A. L. Kazakov, Khim-Farm. Zh., 13, 58 (1979).

10) S. Z. Dziedzic and B. J. F. Hudson, Food Chem., 11, 161 (1983).

11) G. Stenlid, Physiol. Plant., 16, 110 (1963).

12) S. Heitz and C. Mentzen, Compt. Rend., 252, 4214 (1961).

13) L. Farkas, A. Gottsegen, M. Nagradi and S. Antus, J. Chem. Soc., Perkin Trans. 1, 1974, 305.

14) G. Büchi, D. M. Foulkes, M. Kurono, G. F. Mitchell and R. S. Schneider, J. Am. Chem. Soc., 89, 6745 (1967).

15) W. Baker, J. Chadderton, J. B. Harborne and W. D. Ollis, J. Chem. Soc., 1953, 1852.

16) A. G. Perkin and Newbury, J. Chem. soc., 75, 830 (1988).

17) R. B. Bradbury and D. E. White, J. Chem. Soc., 1951, 3447.

18) E. T. Bailey and C. M. Francis, Aust. J. Agric. Res., 22, 731 (1971).

19) H. Finnemore, Pharm. J., 31, 604 (1910).

20) O. R. Gottlieb and A. I. Darocha, Phytochemistry, 11, 1183 (1972).

21) J. Bose and S. Siddiqui, J. Sci. Ind. Res. India, 4, 231 (1945).

22) S. Heitz, Compt. Rend., 254, 4482 (1962).

23) E. Walz, Justus Liebigs Ann. Chem., 489, 118 (1931).

24) W. W. Leavitt and D. M. Meismer, Nature (London), 218, 181 (1968). 